Author: R Ismail and I Tshoose

ANALYSING THE ONUS ISSUE IN DISMISSALS EMANATING FROM THE ENFORCEMENT OF UNILATERAL CHANGES TO CONDITIONS OF EMPLOYMENT

2011 VOLUME 14 No 7

http://dx.doi.org/10.4314/pelj.v14i7.6 


\title{
ANALYSING THE ONUS ISSUE IN DISMISSALS EMANATING FROM THE ENFORCEMENT OF UNILATERAL CHANGES TO CONDITIONS OF EMPLOYMENT
}

\author{
R Ismail* \\ I Tshoose $e^{\star \star}$
}

\section{Introduction}

The main objective of this article is to analyse the issue of onus emanating from the enforcement of unilateral changes to conditions of employment. At the heart of the controversy that faced the Labour Appeal Court ${ }^{1}$ was how to interpret dismissals that appear to be based on operational requirements, and yet at the same time, such dismissals also appear to have the effect of compelling an employee to accept a demand in respect of a matter of mutual interest between the employer and the employee. $^{2}$

The core section in the Labour Relations Act 66 of $1995^{3}$ (LRA) relating to disputes of this nature is section $187(1)$ (c) and the central enquiry to such disputes is whether they are automatically unfair or operationally justifiable. The fine line that determines whether a dismissal is acceptable or not merits an analysis of the overall onus that faces an employer and employee. This analysis is the focus of the article, which deals predominantly with procedural issues. The issue relating to the promotion of collective bargaining will be assessed against the right to dismiss, based on a comparative review of South Africa, the United Kingdom and Canada.

\footnotetext{
* Riaz Ismail. BA (Law), LLB (Natal), LLM (UKZN). Senior Lecturer in Private Law, College of Law, University of South Africa E-mail: ismair@unisa.ac.za.

** Clarence Itumeleng Tshoose. LLB, LLM (North-West University). Senior Lecturer, Department of Mercantile Law, College of Law, University of South Africa E-mail: tshooci@unisa.ac.za.

1 Hereafter the LAC.

2 See Fry's Metals (Pty) Ltd v National Union of Metal Workers of SA 200324 ILJ 133 (LAC), and CWIU v Algorax (Pty) Ltd 200311 BLLR 1081 (LAC).

3 All of the sections referred to herein below are from this statute and therefore direct reference to this Act will not be made in the remainder of this article, to avoid unnecessary repetition.
} 


\section{Understanding the onus issue}

An appropriate starting point is to address the relevant sections in the LRA that impact on the onus issue and to establish their practical applicability to an enquiry in terms of sections 187(1)(c) of the LRA, in the context that faced the LAC in Fry's Metals (Pty) Ltd $v$ National Union of Metal Workers of SA \& Others, ${ }^{4}$ and CWIU \& Others $v$ Algorax (Pty) $L t d .{ }^{5}$ In terms of the $L R A$ with regard to any dismissal, the employee must establish the existence of the dismissal. ${ }^{6}$ Once the existence of a dismissal is established, the onus shifts to the employer to establish that the dismissal is fair. ${ }^{7}$

Additional provisions relevant to the onus issue are that in terms of:

a. Section 185 (a), every employee has the right not to be unfairly dismissed;

b. Section 186 (1)(a), the most basic form of dismissal is when an employer terminates a contract of employment with or without notice;

c. Section 187 (1)(c), it is automatically unfair to dismiss an employee in order to compel the employee to accept a demand in respect of any matter of mutual interest between the employer and employee;

d. Section 188(1)(a)(ii), a dismissal that is not automatically unfair is unfair if the employer fails to prove that the reason for the dismissal is fair, based on the employer's operational requirements.

When a dispute arises about the applicability of the sections referred to above (section 185-188), the onus issue can potentially be interpreted in one of two ways. If the employee relies on section 187(1)(c) as a cause of action, then in terms of section 192(1), the words "any dismissal" could imply that the employee bears the onus of proving the automatically unfair dismissal as it appears to fall within the ambit of "any dismissal". The last two words in section 192(1) are "the dismissal". On a technical level, this could also refer to the specific dismissal which forms the basis

4 Fry's Metals (Pty) Ltd v National Union of Metal Workers of SA 200324 ILJ 133 (LAC) (hereafter the Fry's Metals (LAC) case).

5 CWIU v Algorax (Pty) Ltd 200311 BLLR 1081 (LAC) (hereafter the Algorax case).

6 Section 192(1) LRA.

7 Section 192(2) LRA. 
of the employees' cause of action. So, if the dismissal in question relates to section $187(1)$ (c), the employee bears the onus of proving that the dismissal was effected for the purpose specified therein. If the employee overcomes this onus, the enquiry comes to an end. Where the employee fails to overcome this onus, the employer may still have to prove that the dismissal is fair ${ }^{8}$ in terms of a new enquiry, provided that the employee can establish a dismissal in terms of section 186(1)(a).

On the other hand, a different interpretation could follow relating to the onus. This would mean that in terms of section 192(1), all that an employee needs to prove is the existence of the dismissal, and not explicitly the type of dismissal specified in section 187(1)(c). In other words, to discharge the onus in section 192(1), all the employee needs to prove is that the employer has terminated the contract of employment with or without notice, ${ }^{9}$ after which, the onus will shift to the employer to prove that the dismissal is fair. ${ }^{10}$ If this interpretation is correct the employer bears the onus of proving that the dismissal was not effected for the purpose specified in section 187(1)(c). Where the employer overcomes this onus of establishing that the dismissal was not automatically unfair, the employer will then have the further onus, in terms of section 188(1)(a)(ii), of proving that the dismissal was effected for a fair reason, based on the operational requirements of the employer. This will entail establishing substantive fairness in terms of section 189. It must be borne in mind that in terms of section 188(1)(b), procedural fairness must also be established by the employer.

\section{Critical analysis of sections relevant to the onus of proof}

The first issue of contention which needs to be analysed relates to the question, on whom does the onus rest when section 187(1) (c) is read with section 192 of the LRA. In SACWU v AFROX ${ }^{11}$ the LAC held that section 192(2) provides that once "a" dismissal is established by the employee, [in terms of section 192(1)], the onus shifts to the employer to prove the fairness of the dismissal. The court favoured the interpretation discussed in the preceding paragraph, and reasoned that in the case

8 Section 192(2) read with s 188(1) LRA.

9 Section 186(1)(a) LRA.

10 Section 192(2) LRA.

11 SACWU v AFROX 199920 ILJ 1718 (LAC), hereafter the AFROX case. 
of an alleged automatically unfair dismissal, the employer would have to prove that the dismissal was not contrary to any reason set out in section $187(1)(a)-(f) .{ }^{12}$

The LAC in Afrox referred to "a" dismissal in section 192(1), whereas section 192(1) refers to "the" dismissal. Whilst this appears to be technical, these words have the potential of impacting materially on the onus issue. As explained hereinabove, the word "the" [in section 192(1)] has the potential of imposing the onus on the employee to prove that the purpose of the dismissal falls within the ambit of section 187(1)(c). On the other hand, the word "a" [which is not used in section 192(1)] has a generalised effect and allows the employee to only prove that his employment contract was terminated by the employer with or without notice. ${ }^{13}$ In the latter instance, the employer would then have to prove [in terms of section 192(2)] that the purpose of the dismissal did not fall within the scope of section 187(1)(c).

The words "any dismissal" in section 192(1) also infer an interpretation in favour of the employer, which would include an automatically unfair dismissal. Such an interpretation would mean that the employee needs to establish the automatically unfair dismissal alleged in terms of section 187(1)(c).

Furthermore, the word "fair" in section 192(2) implies a fair reason and a fair procedure when it is read with section 188(1). If section 188(1) does not apply to automatically unfair dismissals, this would effectively render section 192(2) redundant (whenever automatically unfair dismissals exist), because the fairness of a dismissal would need to be assessed only if section 188(1) applies. This raises the question of whether or not section 188(1) has any applicability to an enquiry relating to an automatically unfair dismissal.

The opening words in section 188(1), which read "a dismissal that is not automatically unfair, is unfair if the employer fails to prove....", strongly infer that section 188 becomes applicable only after it has been established that no

12 See AFROX case 1725. For further discussion see Janda v First National Bank 200627 ILJ 2627 (LC). For a different interpretation see Mafomane v Rustenburg Platinum Mines Ltd 200122 ILJ 214 (LC), which was rejected in Janda's case. In any event the decision in Janda's case is consistent with the judgment in the AFROX case and since the latter case was delivered by the LAC it should take precedence over the Mafome case, which is a Labour Court decision.

13 Section 186(1)(a) LRA. 
automatically unfair dismissal exists. This would then mean that section 192(2) has no applicability to an enquiry where an automatically unfair dismissal exists. If this is true, the only sub-section applicable to the "onus" issue relating to automatically unfair dismissals would be section 192(1), which would mean that the employee must establish the existence of the automatically unfair dismissal alleged.

On the contrary it would be more meritorious to hold that had the legislature intended that section 192(2) should not apply to cases relating to automatically unfair dismissals, such a material factor would have been expressly catered for in the statute. Moreover, it is difficult to accept any inference that the legislature could have intended that the employee bear the sole onus of establishing the existence of an automatically unfair dismissal. In any event, the stance taken in Afrox removes any doubt, wherein the court reasoned that in terms of section 192(2) read with section 187(1), for the employer to overcome the fairness element in section 192(2) the employer must prove that the dismissal was not for any reason set out in section $187(1)(a)-(f) .{ }^{14}$

Unfortunately the LRA does not directly/expressly refer to the onus relating to automatically unfair dismissals. However, irrespective of the potential methods of interpreting section 192 (when a dispute relating to an automatically unfair dismissal arises), what matters for purposes of certainty is the way the LAC interpreted the section in the Afrox case..$^{15}$ It should be noted that the court did not contemplate any issue of contention regarding the onus issue. In the Fry's Metals (LAC) case ${ }^{16}$ and the Algorax case ${ }^{17}$ the onus factor was also not raised as a contentious issue, and the LAC in both cases merely sought to establish the purpose of the dismissal in terms of section 187(1)(c).

Based on the reasoning adopted by the LAC in Afrox, ${ }^{18}$ it follows that the onus issue in the context of section $187(1)$ (c) may be set out as follows:

14 See the AFROX case 1725.

15 AFROX case.

16 Fry's Metals (LAC) case.

17 Algorax case.

18 AFROX case. 
(i) The employee needs only to establish the existence of a dismissal, in the simplest form, as is defined in section 186(1)(a), to discharge the onus in section 192(1);

(ii) Thereafter, the employer must prove that the dismissal was not effected for the purpose ${ }^{19}$ set out in section 187(1)(c), to discharge the onus in section 192(2);

(iii) If the employer overcomes the onus referred to in sub-paragraph (ii) hereinabove (which would mean that the dismissal is not automatically unfair), then the employer may need to further establish that the dismissal was effected for a fair reason based on the employer's operational requirements, in accordance with a fair procedure. ${ }^{20}$

This article focuses mainly on the onus referred to in paragraphs (i) and (ii) hereinabove.

\section{The onus of proof which the employee must establish ${ }^{21}$}

The onus under this sub-heading relates to the employee establishing the existence of a dismissal, (even in its most simplest form), as is defined in section 186(1)(a). In other words, the employee needs only to establish that the employer terminated his/her contract of employment with or without notice. On face value, it would appear that it should be easy for an employee to overcome this onus in the context of an allegation of an automatically unfair dismissal in terms of section 187(1)(c). However, it is worth noting certain important points in this regard.

In the Fry's Metals (LAC) case ${ }^{22}$ the court held that there is a difference between a dismissal which is defined in section 186(1)(a) and a dismissal that is contemplated

19 Whilst s 187(1) refers to the reason for the dismissal, the courts in the Fry's Metals (LAC) case and the NUMSA \& Others v Fry's Metals (Pty) Ltd (2005) 26 ILJ 689 (SCA) case agreed that the word "reason" was incorrectly used by the legislature, and the word "purpose" should replace it, as the latter word correctly reflects the intention of the legislature.

20 Section 192(2) read with ss 188(1)(a)(ii) and 188(1)(b) $L R A$.

21 In accordance with s 192(1) LRA. 
in terms of section $187(1)(\mathrm{c}){ }^{23}$ The court reasoned that the former dismissal is final by its nature, whereas the latter dismissal is not final. The latter dismissal is conditional and even intended to be reversible if the employee accepts the demand of the employer. In this regard, the LAC held that "there may be an argument that a dismissal contemplated by s 187(1)(c) - especially if it is understood not to be final does not fit comfortably within the definition of 'dismissal' in s 186(a)." 24 The LAC elaborated that "the argument would be to hold that the dismissal that is contemplated in s 187(1)(c) is not a final dismissal is to give the word 'dismissal' in $\mathrm{s}$ $187(1)$ (c) a meaning that is different from the meaning given to that word in $\mathrm{s}$ 186(a)." 25

In NUMSA \& Others $v$ Fry's Metals (Pty) $L t d,{ }^{26}$ the Supreme Court of Appeal ${ }^{27}$ accepted the reasoning of the court in the Fry's Metals (LAC) case. The LAC held that there is a distinction between a dismissal in terms of section 186(1)(a) and a dismissal in terms of section 187(1)(c), wherein no overlap exists. The SCA confirmed the stance taken by the $\mathrm{LAC}^{28}$ that the difference in the latter dismissal is effected for the specific purpose contemplated in section 187(1)(c), and that that purpose is absent in the former dismissal. ${ }^{29}$ The effect of this reasoning by the LAC and SCA is that a dismissal contemplated in section 187(1)(c) does not fall within the ambit of a dismissal contemplated in section 186(1)(a), because the latter relates only to a final dismissal, whilst the former is not a final dismissal.

The impact of this reasoning by the courts is material in the light of the onus that an employee has to discharge (with reference to section 192(1)), in the context of a section 187(1)(c) enquiry. If an employee relies on section 187(1)(c) as a cause of action and the employee cannot establish the most basic form of a dismissal as is defined in section 186(1)(a), (because the employee's cause of action relates to

22 Fry's Metals (LAC) case.

23 Fry's Metals (LAC) case 147.

24 Fry's Metals (LAC) case 147. Incidentally the court referred to s 186(a) in error, as the correct reference is $s 186(1)(a)$.

25 Fry's Metals (LAC) case 147.

26 NUMSA v Fry's Metals (Pty) Ltd 200526 ILJ 689 (SCA) 708, hereafter the Fry's Metals (SCA) case.

27 Hereafter the SCA.

28 Fry's Metals (LAC) case.

29 Section 186(1)(a) LRA. 
proving a dismissal that is not final, whereas section 186(1)(a) relates only to dismissals that are final), this would mean that the employee is unable to discharge the onus in terms of section 192(1). ${ }^{30}$ The only other way for the employee to discharge the onus in terms of section 192(1) would be to prove the automatically unfair dismissal that is contemplated in section 187(1)(c). This would mean that, indirectly, the employee would bear the overall onus relating to the enquiry as to whether an automatically unfair dismissal exists (which would be contrary to the reasoning adopted in Afrox). ${ }^{31}$

If this line of thinking is taken further, in the event that the result of an enquiry evidences that no automatically unfair dismissal exists there will be no need to establish if the dismissal is unfair in terms of section 188(1) read with section 192(2), as the employee would still be unable to establish that he had been finally dismissed in terms of section 186(1)(a). The consequence of such an interpretation also creates the absurd potential of an employee initially presenting his case and arguing that the dismissal was not final in terms of section 187(1)(c) without success, and consequently in midstream the employee attempting to argue that the dismissal was final, just to establish a dismissal in terms of section 186(1)(a), so that an enquiry can proceed in terms of section 188(1), to establish if the dismissal was fair.

It is appropriate at this point to consider the intention of the legislature in relation to the content of section 187(1)(c). Did the legislature intend for a dismissal under this sub-section to constitute a conditional dismissal, subject to withdrawal if the employer's demand is complied with by the employee? The effect of this question and the concerns raised under this sub-heading are negated if it can be accepted that a dismissal in terms of section 187(1)(c) could fall within the ambit of a section 186(1)(a) dismissal. In order to reach such a conclusion, perhaps, an appropriate starting point is to address the wording in the Fry's Metals (LAC) case, where Zondo JP explained that there may be an argument that a section 187(1)(c) dismissal "does not fit comfortably within the definition of 'dismissal' in s 186(a)." ${ }^{32}$ The words "does not fit comfortably" create the possibility that a section 187(1)(c) dismissal may very

30 To prove that he/she has been finally dismissed.

31 AFROX case.

32 Fry's Metals (LAC) case 147. 
well fit within the ambit of a section 186(1)(a) dismissal, even though not in the most comfortable context. Although Zondo JP did not expressly say so, the inference can be drawn that whilst the purpose contemplated in section 187(1)(c) is not found in section 186(1)(a), that is the only distinction, which in turn does not preclude the hard core fact that a section 187(1)(c) dismissal nevertheless terminates the contract of employment, in the context of section 186(1)(a).

Perhaps a closer analysis of the definition in section 186(1)(a) may provide more assistance in this regard. In terms of section 186(1)(a) a dismissal means that "an employer has terminated a contract of employment with or without notice." In the Algorax case, ${ }^{33}$ the LAC held that the dismissals were conditional in nature. However, the effect of the dismissals was that the employment contracts were terminated with notice, which ought to ensure that they fall within the ambit of a section 186(1)(a) dismissal, irrespective of the fact that the dismissals could potentially be only temporary. Grogan aptly reasons that:

\begin{abstract}
an employer that dismisses employees conditionally subject to an offer of reinstatement if the employee accepts a demand undoubtedly terminates the contract. In that sense, a dismissal occurs; the offer of reinstatement is merely an offer to renew the contract if the condition is satisfied. Whether the contract is deemed to be renewed or the dismissal is deemed to be "revoked" when the condition is satisfied, the nature of the original dismissal does not change. The fact is that the contract was terminated, and the employees remain dismissed until the condition is satisfied, if it is ever satisfied. ${ }^{34}$
\end{abstract}

The reasoning of Grogan clearly relates to basic legal contractual principles. The issue that then arises is that, if an employee relies on section 187(1)(c) as a cause of action by advancing the argument that he interpreted the dismissal not to be a final termination of the employment contract and a court finds that the employer did not intend to finally terminate the employment contract at the time of effecting the dismissal, could it be genuinely said that the minds of the parties were at ad idem that the employment contract was in fact terminated? Again it could be reasoned that there is a meeting of minds that the employment contract is terminated, even if only temporarily.

33 Algorax case.

34 Grogan 2003 ELJ 14 at 18. 
It should be noted that in Mazista Tiles(Pty) Ltd $v$ National Union of Mineworkers \& Others $^{35}$ the LAC endorsed the interpretation adopted in the Frys Metals (LAC) case $^{36}$ and the Algorax case,${ }^{37}$ that section $187(1)$ (c) relates to a dismissal that is not final but conditional in nature.

Despite the points raised under this sub-heading, legal certainty is required as to whether or not an employee will succeed to establish a dismissal in terms of section 186(1)(a) where the existence of an automatically unfair dismissal is alleged in terms of section 187(1)(c), [in order to discharge the onus in terms of section 192(1)]. In this regard it must be accepted that the dismissal contemplated in section 187(1)(c) is a conditional one, as a full bench in two appeal courts (the LAC and the SCA $)^{38}$ have confirmed this. Having accepted the ruling stated in the preceding paragraph, it is highly unlikely that the legislature would intend a "conditional dismissal" in the context of section $187(1)$ (c) to constitute an automatically unfair dismissal yet, at the same time, intend for it not to constitute an ordinary dismissal or termination of a contract of employment in terms of section 186(1)(a).

The wording of section 187(1) begins with "a dismissal is automatically unfair if the employer, in dismissing the employee...", inferring by the use of the words "in dismissing" that the legislature intended the presumption of the existence of an ordinary dismissal when an enquiry is made in terms of section 187.

It is likely that there will be a meeting of minds between the employer and the employee that a termination of the employment contract is intended, even if only temporarily. At the time of the dismissal the employment contract is terminated, and the uncertainty of the revival of the employment contract does not provide any legal basis to change the status of the existing terminated employment contract, which thus falls within the ambit of section 186(1)(a).

35 Mazista Tiles (Pty) Ltd v National Union of Mineworkers 200425 ILJ 2156 (LAC).

36 Fry's Metals (LAC) case.

37 Algorax case.

38 The Fry's Metals (LAC) case and the Fry's Metals (SCA) case. 
The LAC in the Algorax case, ${ }^{39}$ after establishing that an automatically unfair dismissal in terms of section 187(1)(c) did exist, went further to enquire if the dismissal would have been unfair in terms of section 188(1), had the dismissal not been automatically unfair. Having had to assume that if no automatically unfair dismissal did exist, the court could only legitimately probe into an enquiry in terms of section 188(1) if it was satisfied that a dismissal in terms of section 186(1)(a) had been effected.

The courts approach to conducting an enquiry in terms of section 188(1) without establishing if a dismissal in terms of section 186(1)(a) existed conclusively confirms that the LAC considered it so obvious that an ordinary dismissal in terms of section 186(1)(a) existed that it made no mention of such an enquiry. This is the only logical inference to be drawn, otherwise the LAC would have had no legal basis to assess whether or not the dismissal was unfair in terms of section 188(1). This obvious inference drawn from the LAC judgment should serve as a binding authority on a national level.

It is therefore apt to conclude that an employee (in the context of the Fry's Metals (LAC) case and the Algorax case) relying on section 187(1)(c) as a cause of action should be able to establish an ordinary dismissal in terms of section 186(1)(a) in order to discharge the onus imposed on the employee in section 192(1).

\section{The onus of proof which the employer must establish ${ }^{40}$}

As per the reasoning adopted by the LAC in the Afrox case,${ }^{41}$ once the employee establishes the existence of a dismissal, then in terms of section 192(2) the onus shifts to the employer to establish that the purpose for the dismissal does not fall within the ambit of section 187(1)(c). In both the Fry's Metals (LAC) case ${ }^{42}$ and the Algorax case, ${ }^{43}$ the employers presented the argument that the purpose of the dismissal was to satisfy operational requirements. In the former case the LAC

39 Algorax case.

40 In accordance with s 192(2) $L R A$.

41 AFROX case.

42 Fry's Metals (LAC) case 144.

43 Algorax case. 
agreed with the employer, whilst in the latter case the LAC rejected the argument. Since the issue of addressing the purpose of the dismissal relates to substantive fairness, it falls outside the scope of this article. However, it should be noted that in an enquiry in terms of section 187(1)(c) the purpose of the dismissal need not specifically be an operational requirement for the employer to succeed, as any purpose other than the "purpose" specified in section 187(1)(c) will suffice for the employer to overcome this onus.

\section{$6 \quad$ Promoting collective bargaining against the right to dismiss}

\subsection{South African perspective}

Essentially, in both cases the employer's contention was that the dismissal was effected for operational requirements, whereas the employees contention was that the dismissal was effected to compel the employees to accept the employer's demand relating to the new shift system of employment. ${ }^{44}$

Dismissals effected for operational requirements would not fall within the ambit of section 187(1)(c) and would therefore be acceptable in terms of this enquiry, whereas dismissals effected to compel the employees to accept the new shift system of employment would fall within the ambit of section 187(1)(c), and would therefore constitute an automatically unfair dismissal.

In both cases, the LAC had to establish whether the purpose of the dismissal could have both effects, namely, to implement operational requirements and at the same time to compel the employees to accept the employer's demand. In both LAC cases the court held that both effects cannot be present at the time of the dismissal. In this regard, the LAC in both cases held that only one purpose for the dismissal will exist, which will either fall within the ambit of section 187(1)(c) or will not.

However, when confronted with disputes of this nature, an appropriate starting point is to establish whether a matter of "mutual interest" exists between the employer and

44 For general discussion on these cases see Basson et al Essential Labour Law 103-104; Grogan Dismissal 104-108. 
the employee in terms of section 187(1)(c). In both cases the LAC held that a matter of "mutual interest" clearly existed.

In National Union of Metalworkers of S v Fry's Metals, ${ }^{45}$ the Labour Court ${ }^{46}$ held that "in the event of a dispute concerning a matter of mutual interest, such an issue must be resolved by the bargaining process itself which may include a resort to force." ${ }^{47}$ The LC reasoned that the dispute before the court was an interest dispute as it related to the creation of new rights or the diminution of existing rights. ${ }^{48}$ As such it should be resolved by the bargaining process. In this regard, according to the LC, the employer should pursue the bargaining process before dismissing for operational requirements.

The LC held that the employer's failure to continue with the union's proposal to refer the matter for advisory arbitration reflected the employer's intention to avoid the bargaining process to resolve an interest dispute. According to this court, to condone the conduct of the employer, would be inconsistent with the purposes of the LRA, which are to promote orderly collective bargaining and to promote the effective resolution of labour disputes. ${ }^{49}$ This view is consistent with section 3(a) read with sections 1(d)(i) and 1(d)(iv) of the Act. In other words, it appears that the stance taken by the LC was that matters of mutual interest must be resolved by the bargaining process before any consideration is given to the prospect of dismissals to be effected for operational requirements.

On appeal the court in Fry's Metals (LAC) case $^{50}$ rejected the stance taken by the LC. The LAC held that the employer's bargaining right to recourse to a lock-out in terms of section 64 of the Act does not imply that a lock-out is mandatory. The employer may choose to resort to it, and if the employer chooses not to, there is no reason evident in the Act that suggests that the employer should be penalised. In any event, to hold that the employer was obliged to resort to a lock-out assumes that

45 National Union of Metalworkers of SA v Fry's Metals 200122 ILJ 701 (LC) (hereafter the Fry's Metals (LC) case).

46 Hereafter the LC.

47 National Union of Metalworkers of SA v Fry's Metals 200122 ILJ 701 (LC) 706.

48 National Union of Metalworkers of SA v Fry's Metals 200122 ILJ 701 (LC) 706.

49 National Union of Metalworkers of SA v Fry's Metals 200122 ILJ 701 (LC) 712, 713.

50 Fry's Metals (LAC) case. 
the employer effected the dismissals to compel the employees to accept the demand.

The critical point for the LAC was not the consultative or bargaining process but instead whether the purpose of the dismissal was related to operational requirements in terms of section 188(1)(a)(ii). The LAC referred to various sections in the Act, confirming that an employer may dismiss for operational requirements. The fact that the LAC went to the extent of pointing out the legitimacy of a fair dismissal for operational requirements, even in the case of a protected strike, which is a forceful bargaining tool, infers that the right to dismiss for fair operational requirements will take precedence over a legitimate strike, which is a critical powerplay bargaining tool for employees.

Put simply, the LAC rejected the view that matters of mutual interest must be resolved by the bargaining process where dismissals are contemplated and thereafter effected for operational requirements. The LAC certainly did not give priority to the bargaining process wherein disputes of this nature arise. It was clearly evident that the stance taken by the LAC was that if fair operational requirements exist for a dismissal to be effected, the bargaining process to resolve disputes can legitimately take a back seat. In direct contrast, Grogan's interpretation of the stance taken by the LC is that, where a conflict between the employer's right to dismiss for operational requirements and the employees' right not to be dismissed on the grounds of compulsion to accede to a demand exists, the former right must yield to the latter "in cases where the employees have become redundant because of their refusal to comply with their employer's proposal. ${ }^{51}$

It raises the question of whether or not the court in Fry's Metals (LAC) case $^{52}$ has undermined the effect of the bargaining process where an interest dispute arises. Cohen $^{53}$ submits that once a dispute is classified as a rights or interest dispute, its route is predetermined. In the case of the former, the route to be taken is through the adjudication or arbitration process, whilst in the latter case, the dispute is intended to

51 Algorax case 6.

52 Fry's Metals (LAC) case.

53 Cohen 2004 ILJ 1883. 
be resolved through the collective bargaining process. Based on this reasoning, since it appears that a business restructuring dispute is an interest dispute, the predetermined route would be the collective bargaining process. This is in fact the interpretation adopted by the LC. ${ }^{54}$

As Cohen points out, "the LC held that by 'resorting to a dismissal lock-out, under the guise of a retrenchment' the employer was effectively utilising a rights mechanism to remedy an interest dispute that ought to be resolved through collective bargaining. ${ }^{" 55}$ However, the LAC (in the Fry's Metals (LAC) case) ${ }^{56}$ rejected this reasoning by highlighting the importance of protecting the employer when the employer has operational requirements to effect a dismissal. This is consistent with the LAC's reasoning in the Afrox case, that "economics dictate that if it is necessary to shed jobs so that the enterprise may survive or alter or adapt its business then so be it. ${ }^{.57}$ Based on this analysis, it appears that the LAC has undermined the bargaining process wherein interest disputes arise to the extent that it prioritised the right of the employer to dismiss for operational requirements over the utilisation of the bargaining process to resolve interest disputes. This priority, it must be submitted, is not inconsistent with sections 67, 188 and 189 of the Act, which evidences the right to dismiss for operational requirements under certain circumstances.

So how does the view favouring the bargaining process (when interest disputes arise) address the applicability of the right of the employer to dismiss for fair operational requirements? This view is underpinned by the theory of the migration of disputes. What this means is that an interest dispute (emanating from the contemplation/implementation of a restructuring exercise) must start in the bargaining arena and must remain there until the dispute is resolved, except or unless the employer can justify a migration from the bargaining arena to the rights arena. ${ }^{58}$ In the Afrox case ${ }^{59}$ the LAC reasoned that such a migration would be justified if the employer was facing economic collapse. In other words, if the employer started bargaining and his efforts failed, and (under exceptional

54 Fry's Metals (LC) case.

55 Cohen 2004 ILJ 1885.

56 Fry's Metals (LAC) case.

57 AFROX case.

58 Cohen 2004 ILJ 1895.

59 AFROX case. 
circumstances) if the business was facing economic collapse, the employer may then exercise his right to dismiss for operational requirements, thereby legitimately entering the rights arena. Put simply, interest disputes should be resolved in the bargaining arena and only in exceptional circumstances should they legitimately migrate to the rights arena. As stated above, in the context of a section 187(1)(c) enquiry, the court in the Fry's Metals LAC $^{60}$ rejected this view.

It is imperative not to lose focus on the onus issue at this stage of the proceedings. The employer at this stage of the enquiry needs only to establish that the purpose of the dismissal does not fall within the ambit of section 187(1)(c). So how does the migration of disputes have relevance to an enquiry in terms of section 187(1)(c)? The relevance lies in the words "any matter of mutual interest", in section 187(1)(c). Based on one school of thought, if an interest dispute exists (under all circumstances), it must be resolved in the bargaining arena, and if a rights dispute arises, it must be resolved in the adjudication or arbitration process. Hence, the relevance of the theory of the migration of disputes is to interpret the words "any matter of mutual interest" in section 187(1)(c) as establishing which arena or process must be utilised to resolve the dispute.

The court in the Fry's Metals (LC) case ${ }^{61}$ held that the employer should have used the bargaining process to resolve the dispute, but the LAC held that the employer legitimately utilised the rights arena to effect the dismissals for operational requirements. In other words, the LAC's view infers that the rights arena was the appropriate forum to resolve the dispute, whilst the view of the LC is that this migration of disputes is justified only if the threat to the viability of the business is severe enough to warrant the migration. Thompson supports the latter view. ${ }^{62}$ Counsel for the union used the same argument in the Fry's Metals (SCA) case. ${ }^{63}$ Similarly the SCA supported the view of the LAC and rejected the migration approach. The SCA held that the difficulty with the migration of disputes approach is that both the rights and interests disputes overlap in a business restructuring

60 Fry's Metals (LAC) case.

61 Fry's Metals (LC) case.

62 Thompson 1999 ILJ 755.

63 Fry's Metals (SCA) case. 
exercise, and it is this overlap that does not form the basis of the collective bargaining structure that the statute has adopted.

Even Todd and Damant ${ }^{64}$ respectfully reject the migration of disputes approach favoured by Thompson. ${ }^{65}$ Cohen $^{66}$ reasons that despite the clear demarcation of interest and rights disputes, such disputes by their very nature also fall within the ambit of section 189, which relates to restructuring for operational requirements. The SCA therefore dismissed the migration approach because of the unavoidable complexities that stem from it, which it did not view to be the intention of the legislature.

The legal position regarding the migration of disputes in terms of section 187(1)(c) may therefore be summarised as follows:

a. Both interest disputes and rights disputes overlap into the operational requirements arena, and this overlap is complex enough to dismiss the migration of disputes approach in the context of section 187(1)(c).

b. The SCA held that this complexity is avoided if the enquiry starts by addressing the type of dismissal section 187(1)(c) envisages in the light of the basic definition of dismissal in section 186(1)(a). ${ }^{67}$ It is submitted that this approach confirming a rejection of the migration of disputes approach is appropriate, as the wording of section 187(1)(c) clearly infers that a dismissal regarding a matter of mutual interest between an employer and an employee is legitimate provided that the purpose for the dismissal does not fall within the ambit of this sub-section. This confirms that an interest dispute does not need always to be resolved by methods short of dismissal.

c. In any event, the essence of the migration of disputes approach is for the employer to show that the viability of the business came into question or the business was facing economic collapse to justify a migration from the

64 Todd and Damant 2004 ILJ 896.

65 Thompson 1999 ILJ 755.

66 Cohen 2004 ILJ 1883.

67 Fry's Metals (SCA) case 708. 
bargaining arena to the rights arena. The rejection of the migration of dispute approach does not mean that the employee cannot advance the viability/economic collapse argument, but it is respectfully submitted that this argument must be addressed under the enquiry wherein the onus is placed on the employer to establish that the dismissal is fair, based on operational requirements in terms of section 188(1)(a) (ii). This would then eradicate any prejudice against the employee emanating from the rejection of the migration of disputes approach. The only potential prejudice facing the employee is that if he were to be successful relating to such an enquiry, the adjudicator would find that the dismissal was unfair ${ }^{68}$ and not automatically unfair. ${ }^{69}$ However, the court in the Fry's Metals (LAC) case ${ }^{70}$ categorically dismissed the viability (the economic collapse) argument by reasoning that no provision in the LRA exists to justify the argument.

d. The LC's reference to promoting collective bargaining must yield to the right of an employer to dismiss for operational requirements, in the context of an enquiry in terms of section 187(1)(c). This interpretation is favoured in the light of the fact that when there is uncertainty if an interest dispute overlaps into a rights dispute the LRA does not have peremptory provisions dictating which avenue the employer must pursue. ${ }^{71}$ Instead, there are a number of provisions in the statute that grant an employer the election to decide which avenue to pursue. If the employer chooses the dismissal route, that is his right (provided he complies with the Act), and if he/she chooses to resort to a lockout (entering the bargaining arena) that is his/her right as well (provided he/she complies with the statute). Whatever route the employer chooses, nowhere in the LRA does it state that he/she should be penalised for not selecting the alternative route. ${ }^{72}$ Even in the collective bargaining arena, the Constitutional Court (CC) in Ex parte Chairperson of the Constitutional Assembly: In re Certification of the Constitution of the Republic of South

68 In terms of $\mathrm{s} 188(1)$ (a)(ii) $L R A$.

69 In terms of $\mathrm{s} 187(1)$ (c) $L R A$.

70 Fry's Metals (LAC) case.

71 Cf SANDU v Minister of Defence; Minister of Defence $v$ SANDU 20071 All SA 57 (SCA).

72 SANDU v Minister of Defence; Minister of Defence $v$ SANDU 20071 All SA 57 (SCA). 
Africa $^{73}$ highlights the rights or avenues an employer may pursue. These rights or avenues are described in the following passage:

Workers exercise collective power primarily through the mechanism of strike action. In theory, employers, on the other hand, may exercise power against workers through a range of weapons, such as dismissal, the employment of alternative or replacement labour, the unilateral implementation of new terms and conditions of employment, and the exclusion of workers from the workplace (the last of these being generally called a lockout). ${ }^{74}$

It therefore follows that provided that the employer uses these weapons within the confines of the statute the employer will be well within his rights to do so. An appropriate example would be if an employer dismisses employees for operational requirements after failing to effect unilateral changes in conditions of employment. These dismissals will not be automatically unfair if the purpose for the dismissals does not contravene section 187(1)(c). In the circumstances, it is submitted that the migration of disputes approach was appropriately rejected by the appeal courts. ${ }^{75}$ It follows that no onus is placed on the employer compelling him/her to collectively bargain with the employer, in the context of a section 187(1)(c) enquiry.

\subsection{Comparing South Africa to foreign jurisdictions}

Assessing the promotion of collective bargaining against the right to dismiss has invited several discussions from academics following the approach taken by the LAC and SCA. This robust issue merits further investigation as to the stance taken in foreign jurisdictions, in the context of interpreting dismissals emanating from unilateral changes to conditions of employment. In this regard a brief look at the position in the United Kingdom (UK) and Canada will be considered in comparison with the position in South Africa. ${ }^{76}$

The position in UK law appears to be similar to that taken by the South African courts to the extent that consultation may be desirable when considering the enforcement

73 Ex parte Chairperson of the Constitutional Assembly: In re Certification of the Constitution of the Republic of South Africa 199617 ILJ 821 (CC).

74 Ex parte Chairperson of the Constitutional Assembly: In re Certification of the Constitution of the Republic of South Africa 199617 ILJ 821 (CC) 841.

75 Both the Fry's Metals LAC and the SCA cases.

76 See also Petersen Changing Terms to Conditions of Employment LLM Dissertation 2004 chapter 5, 29-36. 
of changes to the conditions of employment, although such consultation or negotiation is not a statutory obligation imposed on the employer. This was highlighted in the case of Hollister $v$ National Farmers, ${ }^{77}$ wherein the applicant was employed as a secretary and, after a decision taken by the headquarters to reorganise its operations, was offered different terms and conditions of employment and different methods of working. Upon his refusal to agree to the new terms he was dismissed. He lodged a claim for compensation for unfair dismissal.

After his claim came before several courts the final appeal was heard in the Court of Appeal. This court held that the Employment Appeal Tribunal erred in its finding that there had not been sufficient consultation or negotiation by the employer with the employee prior to dismissal. The Court of Appeal further held that consultation was not a statutory obligation even though it may be desirable. The Court reasoned that a holistic approach should be taken wherein all of the circumstances are taken into account to determine if the employer acted fairly and reasonably prior to dismissal.

Consultation is merely one of the factors that the court takes into consideration when assessing the fairness of a dismissal. In Hollister the court found that the employee's refusal to accept the changes to the condition of employment justified the dismissal. Similarly, under South African law an employer is not obliged to enter the bargaining arena under such circumstances. Procedurally, the employer can legitimately elect to follow the dismissal route, provided that he/she/it complies with the provisions of the LRA.

In Canada, generally, ${ }^{78}$ there is a body of case law that supports the view that an employer is entitled to make unilateral and even fundamental changes to an employment contract provided that sufficient notice of the change is given to the affected employees. ${ }^{79}$ Procedurally this is also consistent with the stance taken by the South African courts (the LAC and SCA) as alluded to hereinabove, to the extent of prioritising the right of the employer to dismiss for operational requirements.

77 Hollister v National Farmers Union 1979 ICR 542.

78 The word "generally" is repeatedly used because in Canada there are several labour relations systems implemented and they are not all always similarly applied.

79 See Farber v Royal Trust Co 19971 SCR 846; Rosscup v Westfair Foods Ltd 1999 AJ No 944 (QB). 
However, the stance generally taken in Canada is qualified to the extent that an employer may not change the terms and conditions of employment during the duration of the collective agreement. ${ }^{80}$ The employer is allowed to lay off employees during this period ${ }^{81}$ but only for certain bona fide business reasons. A layoff may be permitted by the employer to enforce a unilateral change to the conditions of employment. Upon expiration of the collective agreement and after notice to bargain is given the statute prohibits any changes to working conditions and issues relating to wages until the process of conciliation and a cooling-off period has expired. If an employer implements a lay-off to enforce a demand during this period the action will constitute a statutory violation. It is necessary to consider if certain aspects of the Canadian approach do not offer some benefit to the South African context, in that they would give effect to the provisions of the $L R A$ that encourage collective bargaining. Based on the decisions of the LAC and SCA in interpreting the LRA in its present format, the promotion of collective bargaining must yield to the employer's right to dismiss for operational requirements. Whilst this stance is consistent with the $L R A$, it does raise the issue as to what practical effect the provisions in the $L R A$ that promotes collective bargaining really have in the industrial arena, when employers seek to change conditions of employment.

In terms of section 3(a), the provisions of the $L R A$ must be interpreted as giving effect to its primary objects. Some of these key primary objects are set out in section $1(\mathrm{~d})$, namely to promote orderly collective bargaining, collective bargaining at sectoral level, employee participation in decision-making in the workplace, and the effective resolution of labour disputes. To give practical effect to these rights in the context of this topic, perhaps consideration should be given to providing some statutory protection for South African employees similar to the protection generally afforded (under Canadian law) for the duration of a collective agreement and the intial negotiation period when the parties seek to renew or enter into a new collective agreement. The scope of such protection does not need to be as wide as the

80 See for example s 50 Canadian Labour Code, s 45 British Columbia Labour Relations Code, 1996 and s 59 Quebec Labour Code, RSQ http://www.canlii.org/en/qc/laws/stat/rsq-c-c27/latest/rsq-c-c-27.html all of which makes provision for a "Statutory Freeze" on terms and conditions of employment.

81 Under collective agreements layoffs are temporary suspensions of the employment relationship. See Carter et al Labour Law in Canada 140. 
Canadian approach (as alluded to hereinabove). If employers are prohibited by statute from altering the terms and conditions of employment during some prescribed period (even if it is a limited time period), this would provide employees with stability and result in more meaningful engagement between both parties when the employer seeks to make changes to employment conditions. A statutory inclusion to this effect would give more practical effect to sections $3(\mathrm{a})$ and $1(\mathrm{~d})$ of the LRA. However, ultimately the right to dismiss for fair operational requirements should prevail, and this right available to the employer should not be undermined.

\section{Conclusion}

The procedural issue of onus relating to an enquiry in terms of section 187(1)(c) raises important concerns which have been addressed in this article. Despite these concerns a number of issues have been reasonably clarified.

An enquiry in terms of section $187(1)(c)^{82}$ requires that an employee establish the existence of a dismissal in its most basic form as is set out in section 186(1)(a). To overcome this onus, proving a conditional dismissal as is contemplated in section 187(1)(c) should suffice. Thereafter the employer must establish that the dismissal was not automatically unfair, in that it was not effected for the purpose specified in section $187(1)(c) .{ }^{83}$ If the employer overcomes this onus (which would mean that the dismissal is not automatically unfair), ${ }^{84}$ then the employer may need to further establish that the dismissal was effected for a fair reason based on the employer's operational requirements, in accordance with a fair procedure. ${ }^{85}$

This article has also motivated the endorsement of the ruling by the LAC and SCA in Fry's Metals that the "migration of disputes" approach be rejected. However, whilst a solution of this nature rejects the notion that an interest dispute should migrate to a rights dispute only if the employer is facing extreme circumstances such as economic collapse, an interest dispute must nevertheless start in the bargaining arena, wherein both employer and employee make a concerted effort to resolve the

82 Read with s 192(1) LRA.

83 Section 187(1)(c) read with s 192(2) LRA.

84 In terms of $\mathrm{s} 187(1)$ (c) $L R A$.

85 Section 192(2) read with ss 188(1)(a)(ii) and 188(1)(b) $L R A$. 
dispute in terms of section 189 of the $L R A$ 1995. Furthermore, perhaps the time has come for the South African legislature to consider protecting employees for some prescribed time period from attempts by employers to impose unilateral changes to conditions of employment. This is likely to ensure more effective bargaining between both parties, and it will give practical effect to some of the existing provisions in the $L R A$ which promote collective bargaining in order to resolve labour disputes. In doing so, the right to dismiss for fair operational requirements should ultimately prevail (and not be undermined), as economics primarily dictate if jobs are to be lost. 


\section{Bibliography}

Basson et al Essential Labour Law

Basson A et al Essential Labour Law $5^{\text {th }}$ ed (Labour Law Publications Groenkloof 2009)

Carter et al Labour Law in Canada

Carter DD et al Labour Law in Canada $5^{\text {th }}$ ed (Kluwer Law International The Hague 2002)

Cohen 2004 ILJ

Cohen $\mathrm{T}$ "Dismissals to Enforce Changes to Terms and Conditions of Employment: Automatically Unfair or Operationally Justifiable?" 2004 ILJ 1883-1896

Grogan 2003a EL

Grogan J "Chicken or egg? Dismissals to enforce demands" 2003 EL Vol. 19 (2) April 2003 4-12

Grogan 2003b EL

Grogan J "Termination lockout: A fatal condition" 2003 EL Vol.19 (6) 14-24

Grogan Dismissal;

Grogan J Dismissal (Juta Cape Town 2010)

Petersen Changing terms to conditions of employment

Petersen D Changing terms to conditions of employment in the South African labour relations arena - the approach of the courts: A comparative analysis LLM Dissertation submitted at the University of Western Cape 2004 chapter 5 November 2004.

Thompson 1999 ILJ

Thompson C "Bargaining Business Restructuring and the Operational Requirements Dismissal" 1999 ILJ 755-769 
Todd and Damant 2004 ILJ

Todd C and Damant G "Unfair Dismissal - Operational Requirements" 2004 ILJ 897-900

\section{Internet sources}

Quebec Labour Code, RSQ http://www.canlii.org/en/qc/laws/stat/rsq-c-c27/latest/rsq-c-c-27.html

Quebec Labour Code, RSQ http://www.canlii.org/en/qc/laws/stat/rsq-c-c27/latest/rsq-c-c-27.html accessed 6 December 2011

\section{Register of legislation}

British Columbia Labour Relations Code, 1996

Canadian Labour Code, 1985

Labour Relations Act 66 of 1995 (LRA)

\section{Register of cases}

CWIU v Algorax (Pty) Ltd 200311 BLLR 1081 (LAC)

Ex parte Chairperson of the Constitutional Assembly: In re Certification of the Constitution of the Republic of South Africa 199617 ILJ 821 (CC)

Farber v Royal Trust Co 19971 SCR 846

Fry's Metals (Pty) Ltd v National Union of Metal Workers of SA 200324 ILJ 133 (LAC)

Hollister v National Farmers Union 1979 ICR 542

Janda v First National Bank 200627 ILJ 2627 (LC)

Mafomane $v$ Rustenburg Platinum Mines Ltd 200122 ILJ 214 (LC)

Mazista Tiles (Pty) Ltd v National Union of Mineworkers 200425 ILJ 2156 (LAC)

National Union of Metalworkers of SA v Fry's Metals 200122 ILJ 701 (LC)

NUMSA v Fry's Metals (Pty) Ltd 200526 ILJ 689 (SCA)

Rosscup v Westfair Foods Rosscup v Westfair Foods Ltd 1999 AJ No 944 (QB) 
SACWU v AFROX 199920 ILJ 1718 (LAC)

SANDU v Minister of Defence; Minister of Defence $v$ SANDU 20071 All SA 57 SCA

\section{List of abbreviations}

$\begin{array}{ll}\text { BLLR } & \text { Butterworths Labour Law Reports } \\ \text { CWIU } & \text { Chemical Workers Industrial Union } \\ \text { EL } & \text { Employment Law } \\ \text { ILJ } & \text { Industrial Law Journal } \\ \text { LAC } & \text { Labour Appeal Court } \\ \text { LC } & \text { Labour Court } \\ \text { LRA } & \text { Labour Relations Act } \\ \text { NUMSA } & \text { National Union of Metalworkers of South Africa } \\ \text { SACWU } & \text { South African Chemical Workers' Union } \\ \text { SANDU } & \text { South African National Defence Union } \\ \text { SCA } & \text { Supreme Court of Appeal }\end{array}$

